\title{
Gesture in the Work of Rabelais
}

\author{
EVA KUSHNER
}

To say that the status of gesture in Rabelais' novel is a privileged one would be an understatement. Literary historians and critics have noted that the world of Rabelais is a world of perpetual and dynamic motion which, far from being random, is highly organized and structured. For this reason more recent critical theory, insofar as it points to gestural codes as paralinguistic phenomena, enables us to study gesture in Rabelais from a semiotic point of view. One danger of so rich a subject is that it scatters one's inquiry, leading one to pursue too many paths at once. It is also dangerous to visualize Rabelais' text through the eyes of one or another of the relevant theoreticians, at the sacrifice of perceiving its full aesthetic richness. If there is a text which resists being reduced to any one interpretative approach, it is the Rabelaisian text. As far as it is concerned, in the beginning is, indeed, the word. But this word, this verbal text, is interwoven with a wealth of other texts, within and without, in the wider sense given to 'text' today; and these texts are governed by codes of their own, which Rabelais makes accessible to the reader through the magic of connotation. We shall deal, briefly, with four aspects of Rabelais' use of gesture: the presence and role of gesture in the text, as exemplified by Rabelais; the wider cultural links and echoes called forth by the representation of gesture in the Renaissance context; the modernity of Rabelais in terms of the almost obvious applicability of semiotic inquiry to his world; and, finally, the inability of semiotics itself to account for his humanistic treatment of meaning.

To evoke gesture in Rabelais is to speak of the joy of life, of the body and of bodily motion. The excerpt in the Prologue to Gargantua that deals with the little dog struggling with a bone, as the reader should struggle with the text, to make them yield their respective substantial marrow, is pace-setting in its frenzied, yet purposeful mobility:

Did you ever pick a Lock to steal Wine-bottles? Tchuck! Recall to your Memory the Countenance you then wore. But did you ever see a Dog encountering some Marrow-bone? He is as Plato says the most philosophical 


\begin{abstract}
Animal in the World. If you have seen him, you may have noted with what Devotion he watches it, with what Care he guards it, how fervently he holds it, and with what Diligence he sucks it ... In imitation of this Dog it becomes you to be wise, to smell, to feel and value these goodly Books stuffed with lofty Matters, easy in the Pursuit and tough in the Encounter, and then by careful Reading and frequent Meditation to break the Bone and suck the substantial Marrow. ${ }^{1}$
\end{abstract}

When you consider that what is meant here is the innermost secret of spiritual life, you immediatley grasp the extent to which, stylistically, thought in the Rabelaisian text is translated in terms of action, or what linguists would call process. Now all movement is not gesture, nor is all gesture voluntary or programmed motion. For the latter, Greimas uses 'motricité' rather than 'mobilité' 2 and we may incorporate this semantic feature into all treatment of gesture, since even the little dog, whose activity in the everyday world would normally be regarded as instinctual, is portrayed by Rabelais as engaging in a highly structured, finely programmed, and decidedly purposeful activity. The suggested gesture contaminates even the reader - at least, the implicit reader; Rabelais has done more than perhaps any other writer to project the reader-in-the-text into concrete reality by constant interpellations and other phatic devices. The reader is thus provoked, at the very outset of Gargantua, to empathize with Rabelais' world of purposeful activity. It must be noted, however, that purposeful activity belongs only to the helpful actors in the text, not to the opponents whose gesture, if programmed at all, is nevertheless usually directed towards chaos. An excellent example of this appears in Chapter 27 of Gargantua, where Friar John is defending the garden of Seuillé against the invasion from Lerné. Every attempt to hide, to flee or to resist is met by merciless, almost rhythmic beating. The enemies scatter because they were motivated by their disorderly desire to steal grapes, whereas the staff of the cross, with a motion not unlike that of the reaper's scythe, but infinitely more violent, regularly hits at least one enemy per beat:

... he threw down his great Monk's Habit and laid hold of the Staff of the Cross, which was of the heart of Service-tree, as long as a Lance, rounded for a good Grip, and a little decorated with Fleur-de-Lys almost all effaced. Thus he set forth in a fine Cassock, put his Frock scarfwise, and with his Staff of the Cross laid about him lustily on his Enemies, who without Order or Ensign, Trumpet or Drum, were gathering in the Vineyard. ... He fell upon them, I say, so stiffly, without giving Warning, that he overthrew them like Hogs, striking all at random in the old Fencing fashion. (p. 112)

Now the expression 'at random' (à tort et à travers) does not seem to tally with the above-mentioned concept of purposeful activity, unless it 
is linked with what follows: wherever Friar John strikes one of his unaimed blows - and somehow the joy of not having to aim adds yet another element of superb organization - he finds a target; and though each blow has a different anatomical result, all blows have a common finality:

For some, he beat out their Brains, for others, he broke their Arms and Legs; for others, he disjointed the Bones of their Neck; for others, he demolished their Kidneys, slit their Nose, blackened their Eyes, gashed their Jaws, knocked their Teeth down their Throat, shattered their Shoulder-blades, mortified their Shanks, dislocated their Thigh-bones, disabled their forearms. (Ibid.)

Examples of the contrast between the motor behaviour of Gargantua's troops and Picrochole's troops are countless. Among the most visible and studied examples are the acrobatic demonstrations performed by Gymnaste on his horse in order to attract the attention of a whole squadron of Picrochole's soldiers, to fascinate them with his incredible dance, and then to kill Tripet and all the others with the greatest ease, all while they were watching him, mesmerized, and thinking they were seeing the devil himself. Gymnaste twirls his entire body resting only on his thumb between the horse's ears, and after dismounting he is able, just like Friar John in the earlier scene, to befall each of his enemies and bring him into a state of complete physical and psychological disarray.

Since our last two examples were taken from the war it might seem that we are concentrating upon the gesture of violence. This is, to some extent, necessary, for two reasons. First, war is an important theme in Pantagruel, Gargantua, and in the Fourth Book, where it becomes even more allegorical. This predominance of war may seem paradoxical, since Rabelais abhors war as a solution to social and political problems. Like Voltaire two centuries later, he reduces war ad absurdum by showing the link between irrationality and war, and on the other hand, reason and peace. But if there must be war, then a righteous cause-which can be only self-defence - has on its side not only justice but also skill and good strategy. According to his usual technique of fictionalizing human problems, Rabelais must delve into the irrational to call forth the rational, and therefore he portrays brutal violence in order to oppose it to elegant violence, which in turn is lustily portrayed and pursued for its own sake. There are many scenes in Rabelais in which gesture is cultivated for its own sake; war scenes are only one type among these, but an obvious and important type, enabling the author to enact for himself, and for the reader, a competition, so to speak, between gesture and word. In this context, it must not be forgotten that the war of the Dipsods and that of Picrochole rest on medieval literary traditions which Rabelais has 
chosen as the narrative framework for his book. In connection with the gesture of violence, it is not the 'tall tale' aspect of this tradition which makes it important for us, but its humanistic reorientation.

The other reason for our emphasis on violence is that, as Bakhtin has shown, ${ }^{3}$ Rabelais dramatizes important aspects of popular consciousness, one of which is the carnivalisation of violence. He presents the literary translations of the ritual reversals of dominance in ancient and medieval festivities, and thus provides the continued literary re-enactment of permanent, almost archetypal situations. What Bakhtin says about the revenge of the body against the soul has implications that are not limited to the Renaissance. They do, however, emerge in the Renaissance, and they symbolically culminate in Rabelais. The kind of gesture we are discussing may therefore be so different from that discussed by Professor Chastel as to be its antithetic complement: the gesture of violence, to which we should add the pornographic, the scatological, the nutritional. Rabelais does not contradict the more refined gestural codes, but he playfully and forcefully draws our attention to their reverse, and complementary side. That the grotesque representation - or misrepresentationof noble gestures satirizes pretensions of nobility and high-mindedness is also part of the Rabelaisian vision and, for that matter, of Rabelais' historical function among Renaissance writers. Let us recall the scene in which Eudemon is introduced to Gargantua as his new tutor, after the abysmal mismanagement of Gargantua's education by his scholastic masters. Because Rabelais has read Castiglione, and is perfectly aware of the courtly code of deportment in all its ramifications and implications, Eudémon with his over-refinement is more wretched than Gargantua. This must be quoted in French, and read as a text linking gesture, attitude, intonation, pronunciation, rhetorical style and choice of dress in one satirical portrait:

Alors Eudémon, demandant congié de ce faire au vice-roy son maistre, le bonnet au poing, la face ouverte, la bouche vermeille, les yeulx asseurez et le reguard assis sur Gargantua, avecques modestie juvénile se tint sur ses pieds, et commença le louer et magnifier premièrement de sa vertus et bonnes meurs, secondement de son sçavoir, tiercement de sa noblesse, quartement de sa beaulté corporelle et, pour le quint, doucement l'exhortait à révérer son père en toute observance, lequel tant s'estudioit à bien le faire instruire, enfin le prioit qu'il le voulsist retenir pour le moindre de ses serviteurs, car aultre don pour le présent ne réquéroit des cieux, sinon qu'il lui feust faict grace de luy complaire en quelque service agréable. Le tout feut par icelluy proféré avecques gestes tant propres, pronunciation tant distincte, voix tant éloquente et langaige tant aorné et bien latin, que mieulx ressembloit un Gracchus, un Cicéron ou un Émilius du temps passé qu'un jouvenceau de ce siècle. Mais toute le contenance de Gargantua fut qu'il se print à plorer comme une vache, et se cachoit le visage de son bonnet, et ne 
fut possible de tirer de luy une parolle non plus qu'un pet d'un asne mort. (p. 83)

One detail among others to be noticed is the use of the hat; here the two characters stand in direct contrast. Eudémon holds his 'bonnet au poing' like a falcon, or a weapon, in tense readiness and by dint of a conscious plea for social acceptance and progress. Gargantua uses his hat as clumsily as his body - to hide his shame, embarrassment and wretchedness. We have before us two extremes of gesture, one of excessive organization, one of lack of organization, both opposed to the humanistic ideal of bodily and mental harmony.

Up to this point we have considered various examples of gesture and its role in Rabelais' writing. This should now be systematized. Gesture is part of a narrative world in motion both in the sense of 'mobilite' and 'motricité', that is, one endowed with an element of voluntary human activity, organizing and constructive. This activity, in turn, fits into a vision which asserts the importance and the joyfulness of the body and all its manifestations; and it can be subsumed, either under the myth of Physis, that is, the positive and infinitely creative concept of nature, or what appears as Anti-Physis, its distorting and destructive opposite. Stylistically, that which pertains to Physis is portrayed as harmonious, while that which pertains to Anti-Physis is dissonant, grotesque, distorted, and thereby ridiculed in every possible way. At a still more general level of semantic integration, it could be said that because such positively or negatively predicated bodily action occurs in time and space, gesture thus becomes emblematic of Renaissance fictionality itself, with its conquest of time and space. Within this 'modélisation', there are models and anti-models which underpin gesture in a positive or negative direction. For example, the propensity of the Papimanes to kneel down, and to kiss whatever is presented to them, especially if it has even the remotest relationship with the Pope, is a symptom of their religious and political enslavement. Pantagruel, on the other hand, can view the sacred decretals with aristocratic detachment. The bejewelled book was tied to the portals of the church with chains of gold and hung very high above the heads of ordinary mortals, both for its safety and as a sign of respect. Pantagruel alone could see it face to face, so to say, because of his height: 'Nous le regardions en admiration. Pantagruel le manyoit et tournoyt à plaisir, car il y pouvoit aizément toucher.' (p. 711) This serves to make the contrast between Pantagruel's lofty detachment and the prostrate stupidity of the Papimaniacs even more striking.

Thus models and anti-models have textual indicators in the text, which may be briefly noted. Besides such brief notations, and in contrast to them, there are very long passages where gesture and the gestural code 
obviously stand on their own, and are developed for their own sake. The gestural domain can have a distinct aesthetic existence, even though this distinctness can never be complete, and so the exact mode of relating gesture to other modes of communication should be watched. A good example is the scene in the Third Book (chapters 19 and 20) where, upon the advice of Pantragruel, Panurge consults a mute man regarding the problem of his marriage. It is noteworthy how Pantagruel explains why a mute man should be among the consultants in Panurge's search for an answer, which according to Saulnier is expressive of Renaissance man's quest for truth. ${ }^{4} \mathrm{Natural}$ languages are arbitrary conventions; words do not hold meanings in themselves, but by dint of an intervention of man's choice (and could it not be said that by poking fun at pedantic speech by inventing sign languages Rabelais, ahead of Saussure, drew attention to the arbitrariness of sign and the separateness of signifier and signified?). Since other systems than languages convey meanings, Pantagruel urges Panurge to seek the advice of a mute in order to benefit from a natural, as opposed to a contrived mode of prognostication. Nazdecabre is therefore summoned, and just as in the Thaumaste scenes where all the arguing is done by gestures, all the action is performed by Nazdecabre in silence. Panurge also asks questions in his own, grotesque brand of sign language, with Pantagruel acting as interpreter. The result is that this scene has the same rhythm as every other episode of the Third Book, following Rabelais' fictionalization of hesitancy and doubt (there are, after all, as many arguments for being married as there are arguments against it). Furthermore, the mute's gestures become more and more complicated, insistent and aggressive, which irritates Panurge to the point of wanting to beat up his unfortunate advisor. Rabelais' message seems to be that attention must be paid to this alternative system of signs because it is alternative, and therefore may, by attracting attention to its difference, make Panurge (and the reader) reflect upon the uncertainties of communication, the elusiveness of meaning, and the ultimate unattainability of truth, which in turn draws attention to these problems when they beset verbal communication. ${ }^{5}$ As with Thaumaste, so with Nazdecabre, the gesticulation itself is grossly comic.

It is clear that, mutatis mutandis, Rabelais is ridiculing the same attitudes when it comes to verbal communication, as in the case of the scholar from Limousin and Janotus de Bragmardo, the ludicrous Sorbonne professor; or to written communication, as in the judicial dispute of the two noblemen, Humevesne and Baisecul. Here is a very small sample from the beginning of the Nazdecabre scene:

[Panurge] baisla assez longuement, et, en baislant, faisoit hors la bouche, avecques le pouce de la main dextre, la figure de la lettre grecque dicte Tau, 
par fréquentes réitérations. Puis leva les oeilz au ciel, et les tournoyoit en la teste comme une chèvre qui avorte, toussoit ce faisant, et profondément souspiroit. Cela faict, monstroit le défault de sa braguette [i.e. the absence of a cod-piece, since for symbolical reasons he had renounced wearing one at the outset of his search for an answer]; puys souz sa chemise print son pistolandier à plein poing, et le faisoit mélodieusement clicquer entre ses cuisses; se enclina fléchissant le genoil gauche, et resta tenent ses deux braz sus la poictrine, lassez l'un sus l'autre. Nazdecabre curieusement le reguardoit, puis leva la main guausche en l'aër et retint clous en poing tous les doigtz d'icelle, excepté le poulce et le doigt indice, desquelz il acoubla mollement les deux ongles ensemble. J'entends, dit Pantagruel, ce qu'il praetend par cestuy signe. Il dénote mariage, et d'abondant le nombre trentenaire, scelon la profession des Pythagoriens. Vous serez marié. (p. 44)

Then the scene almost degenerates into a free-for-all, because Panurge and Nazdecabre are obviously not understanding each other (but then it is also part of the entire framework of the Third Book that Panurge leaves his consultants upon a misunderstanding, so that the suspense may continue). Pantagruel underscores the autonomy of signs and the fact that Panurge has become angry at the code or the gestural utterance, only as a pretext; at the 'énonciation' instead of the 'énoncé'. This, of course, is also part of Panurge's hedging before a decision. 'Si les signes vous faschent, o quant vous fascheront les choses signifiées! Tout vrai à tout vrai consonne' [Thus any true signifier corresponds to a true signified] . . . 'Le mut praetend et dénote que serez marié, coqu, battu et dérobé.' (p. 444) Before we leave this scene and the typology of gestural discourse in Rabelais' novel we must distinguish the gestures of the giants from those of Panurge, Friar John and all ordinary human beings on whatever side. As the book progresses away from its medieval framework the giants become more and more assimilated to the human actors in the book. There is a tendency throughout, however, for the giants to be masters of discourse, to harangue others. When they act, they act masterfully. When they teach, they are heeded. When they fight, they win. It is as if ordinary mortals, with Panurge as their prototype, had far greater need of the multifarious mediation of gesture. The giants' gestures are few and totally purposeful; but the same could be said of their verbal utterances, and this illustrates from another point of view the interrelatedness of the two media of expression.

Let us now briefly consider some highlights of the critical reception of gesture in Rabelais. Although perspectives upon Rabelais' textualization of bodily activity differ widely, they all espouse or even vindicate Rabelais' ultimate optimism. They all regard the complementarity, indeed the alternation, of word and gesture, and the flowing together of speech acts and bodily expression, as indications that communication exists if only we make it exist. Communication may exist between and 


\section{4 / Renaissance and Reformation}

among the fictional characters just as it may exist between the author and the reader, both under the same conditions of struggle against ignorance and inhumanity. Special mention must be made here of Alfred Glauser's Rabelais créateur $^{6}$ where, in the context of the movement that has occurred in French studies away from positivistic criticism towards intrinsic text analysis, a new path has been blazed in the stylistic grasp of Rabelais through his text. How does Rabelais become the text, so to speak? Though he does not make this suggestion himself, Glauser tempts me to link the French word 'geste' in the feminine, which means epos (as in 'chanson de geste'), and 'geste' in the masculine, meaning gesture. I believe this to be true because the five books of Gargantua are a mock epic where, through the gestures of individual heroes and anti-heroes, we find arising before our eyes a world of expression and self-expression as free as could be found in the middle of the sixteenth century - even if, according to Febvre, no one, not even Rabelais, could tread the path of unbelief to its very end. It is an expanding world in more ways than one: through spatial conquest, through conquest of knowledge, through the deployment of physical activity such as sports and play and, if certain interpretations of the 'pantagruélion' are correct, even through economic activity in the commercial sense as well as in the sense of the economy of grace. Thus Rabelais has captured in his novel the maximum of freedom, mobility and joyous activity that the imagination of his time could muster, thereby making his novel a kind of microcosm of his time.

The second point towards which Glauser's interpretation impels me is this. As a committed writer, Rabelais textualizes the dynamics of his rejection of social abuse and his own impulse towards humanistic activity. In this manner, according to Glauser, each episode not only justifies itself as fiction but contains the author: ". . . pour Rabelais ces scènes correspondent à un besoin de mouvement. L'acte d'écrire devient un des seuls actes possibles, mais qui, ne se satisfaisant jamais, doit être recommencé à chaque épisode." The characters are in the process of becoming because Rabelais allows them to develop and to keep him company. There is, Greimas reminds us, something unfinished about a gesture, and thus a gesticulating character allows a greater measure of creative indeterminacy than does a character solely characterized by verbal expression. ${ }^{8}$ Where there is indeterminacy and ambiguity, at least at the level of interaction between the actors, we may truly have an 'opera aperta,' and one, furthermore, which makes for a dialogical rather than a monological situation.

To return to Glauser, Rabelais' sense of gesture underpins his own capacity for animating a world of metamorphosis. There is life, because gestures are never definitive or finished. To say that Rabelais' style is 
life-like would be an understatement; iconically or metonymically, it is life in the same way as Montaigne's text is thought in its progression. Rabelais, says Glauser,

est né avec un style pluriel et ce sera selon quelques influences et inspirations du monde extérieur qu'il le mettra en mouvement, mais ce sera surtout parce que ce style demande une proie ... Si le style est nécessaire à l'action que l'écrivain entreprend de traduire, l'action est aussi nécessaire au style. Rabelais se plait à faire vivre devant lui un adolescent géant pour qui la journée n'était point passée sans profit. S'il a une telle énergie, s'il est pris dans un tel tourbillon de gestes, c'est surtout parce que l'auteur veut écrire. 9

But that is the problem. It is not possible in this time of 'hésuchisme', of profound silence regarding the essential, to openly say what one would like to say, but there are many ways of encoding one's secret thoughts, and Rabelais' way is to entrust it to feverish activity, even to aggression that is directed towards the worst in man, so that the best may be liberated.

This brings us to the wider cultural links of Rabelais' gestural text in the context of the Renaissance. In this connection Bakhtin's ideas are too well known to be summarized here, except for this: while Glauser is able, from a psychological point of view, to demonstrate how Rabelais deals with his feelings of protest - as a kind of self-fulfilling dream - Bakhtin brings out the immense positiveness and the social value of this process by showing that corporality, with its gestural support, is the element of sanity and therefore of salvation in Rabelais; especially the way in which Rabelais has exorcised, following popular tradition, anything that may have been thought to relate to the lower part and functions of the body. In the carnivalesque process the upper and the lower become truly reversed. One of the most important categories of gesture in this respect is beating and dismemberment. In Bakhtin's thought, this is always symbolically directed at the king (and following certain indications of socio-psychoanalysis we might also add, at the father).

The grotesque beating of the justice-distorting Chicanous in Book Four is an excellent example. Again, there are parodic crownings as well as dethronements, and disguises of kings, both in the case of Anarche and of Picrochole after their respective defeats. Such beatings, such dethronements, as well as acts of sexual aggression and amazing sexual abundance that characterize the world of Rabelais, are metaphorical enactments of struggle against political and religious arbitrariness. 'A la base de la littérature progressiste de la Renaissance résidait cette ferme conviction qu'il est nécessaire et possible de se dégager totalement de la véritable structure de cette vie. ${ }^{10}$ Art as art is action, transforming and 
transformed. That is why Rabelaisian art, as seen by Bakhtin, does not merely 'represent' gesture; it is gesture.

That is extreme confidence. At the other end of the spectrum, certain semiotic views of gesture are sobering, especially J. Kristeva's, who at first sight appears to take gesture as a means to destabilize simplistic philosophies of meaning. ${ }^{11}$ If gesture is just another communicative code within the text, it merely serves static communication, as if meaning were a content that you could pour from one container into another. If, then, gesture is not a semiotic praxis, it must merely parallel other static codes such as phonology, and as such cannot be productive. However, it can be productive, that is, liberating, precisely to the extent to which it cannot be reduced to correspond to verbal meanings, but instead indicates realities still in the making. Here, we can see applications to gesture in Rabelais because he uses it to awaken the reader to the ineffectual nature of gesture and word. Kristeva feels that the American schools of kinetics, by developing gestural codes independent of verbal codes and therefore being anthropologically helpful, are too positivistic and intertextualistic; their conceptual tools will encounter the same limitations as verbal codes. ${ }^{12}$ What appears to Kristeva to be creative, at the time of writing Semeiotike, is the study of the differential of gesture in conjunction with the study of non-Western cultures. By this means the anaphoric function of gesture, which insists on indicating the other, can be better understood. We can then reinterpret gesture as semiotic praxis, in the pragmatic sense and in the direction of lesser determinacy. Because of his own humanistic reflection upon the unreliability of fixed codes, Rabelais appears to have prefigured and fictionalized in his own manner the ambitions, and the self-doubts, of this particular semotic approach.

Greimas' ambition with respect to gesture in $D u$ sens is not without affinities to our subject: it is Greimas' intention to integrate man's semiotic relationships, including bodily motion, into those of the world of nature as a matter of knowledge. Like Rabelais', it is an encyclopedic ambition, a search for a universal system that will include gesturality as a sub-system endowed with symbolical qualities when unfolded as myth. ${ }^{13}$

With respect to gesture, it is François Rigolot's analysis, with its distinction of three levels of the manifestation of gesture, which seems the most faithful to Rabelais: the gestural language of the characters themselves, their verbalization by the narrator, and the consequent exchange of signification between author and reader. ${ }^{14}$ When we take these three levels into account, we are not left in mid-air, that is, we are not caught in the infinite reverberation of semiotic relations seen by Greimas; we are saved from this inferno of signs and confronted again with the meaningful 
world of original values which is that of Rabelais. Blind application of today's semiotic approaches to these values would be anachronistic and therefore counterproductive. It is not necessary to give Rabelais a modernistic colouring with respect to the history of meaning but to show the dialogue between his endeavours and the endeavours of those who today attempt to save the human word from becoming a 'parole gelée'. The humanistic warning to semiotics, across the ages, is that any system can become 'parole gelée'.

\section{McGill University}

\section{Notes}

1 Rabelais, The Five Books and Minor Writings, a new translation with notes by W.F. Smith (London 1893) 6-7. In subsequent quotations from this translation, page references to it will be given immediately after the excerpt. For the French text, references are to the Oeuvres complètes, édition établie, annotée et préfacée par Guy Demerson (Paris 1973); page references will again be given immediately following the quote.

2 Algirdas Julien Greimas, Du sens, essais sémiotiques (Paris 1970) 57-82.

3 Mikhail Bakhtin, L'Oeuvre de François Rabelais et la culture populaire au Moyen Age et sous la Renaissance, traduit du russe par Andrée Robel (Paris 1970).

4 Verdun-Louis Saulnier, Le dessein de Rabelais (Paris 1957).

5 Between Gargantua (1534) and the Third Book (1542), Des Périers' Cymbalum mundi (Lyons: Bonnyn, 1538) had also dramatized the laughable powerlessness of speech and the virtue of silence.

6 Alfred Glauser, Rabelais créateur (Paris, 1964).

7 Glauser, 24.

8 Greimas, 70-82.

9 Glauser, 15-16.

10 Bakhtin, 274. Bakhtin himself is quoting from Dobroliubov, Poésies d'Ivan Nikitine. Oeuvres choisies en VI volumes (Leningrad) 167.

11 Julia Kristeva, Séméiotikè, recherches pour une sémanalyse (Paris 1969) 90-112.

12 Kristeva, 112.

13 Except that Rabelais himself would not systematize but let the reader draw his own conclusions.

14 François Rigolot, Les langages de Rabelais (Genève 1972). 